\title{
Quarterly Environmental Radiological Survey Summary First Quarter 1995 100, 200, 300, and 600 Areas
}

\author{
S. M. McKinney
}

Date Published

April 1995

DISCLAIMER

This report was prepared as an account of work sponsored by an agency of the United States Government. Neither the United States Government nor any agency thereof, nor any of their employees, makes any warranty, express or implied, or assumes any legal liability or responsibility for the accuracy, completeness, or usefulness of any information, apparatus, product, or process disclosed, or represents that its use would not infringe privately owned rights. Reference herein to any specific commercial product, process, or service by trade name, trademark, manufacturer, or otherwise does not necessarily constitute or imply its endorsement, recommendation, or favoring by the United States Government or any agency thereof. The views and opinions of authors expressed herein do not necessarily state or reflect those of the United States Government or any agency thereof.

Prepared for the U.S. Department of Energy Office of Environmental Restoration and Waste Management

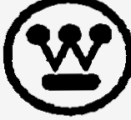
Hanford Company Richland, Washington

Hanford Operations and Engineering Contractor for the

U.S. Department of Energy under Contract DE-ACO6-87RL10930

Approved for Public Release 


\section{DISCLAIMER}

Portions of this document may be illegible in electronic image products. Images are produced from the best available original document. 


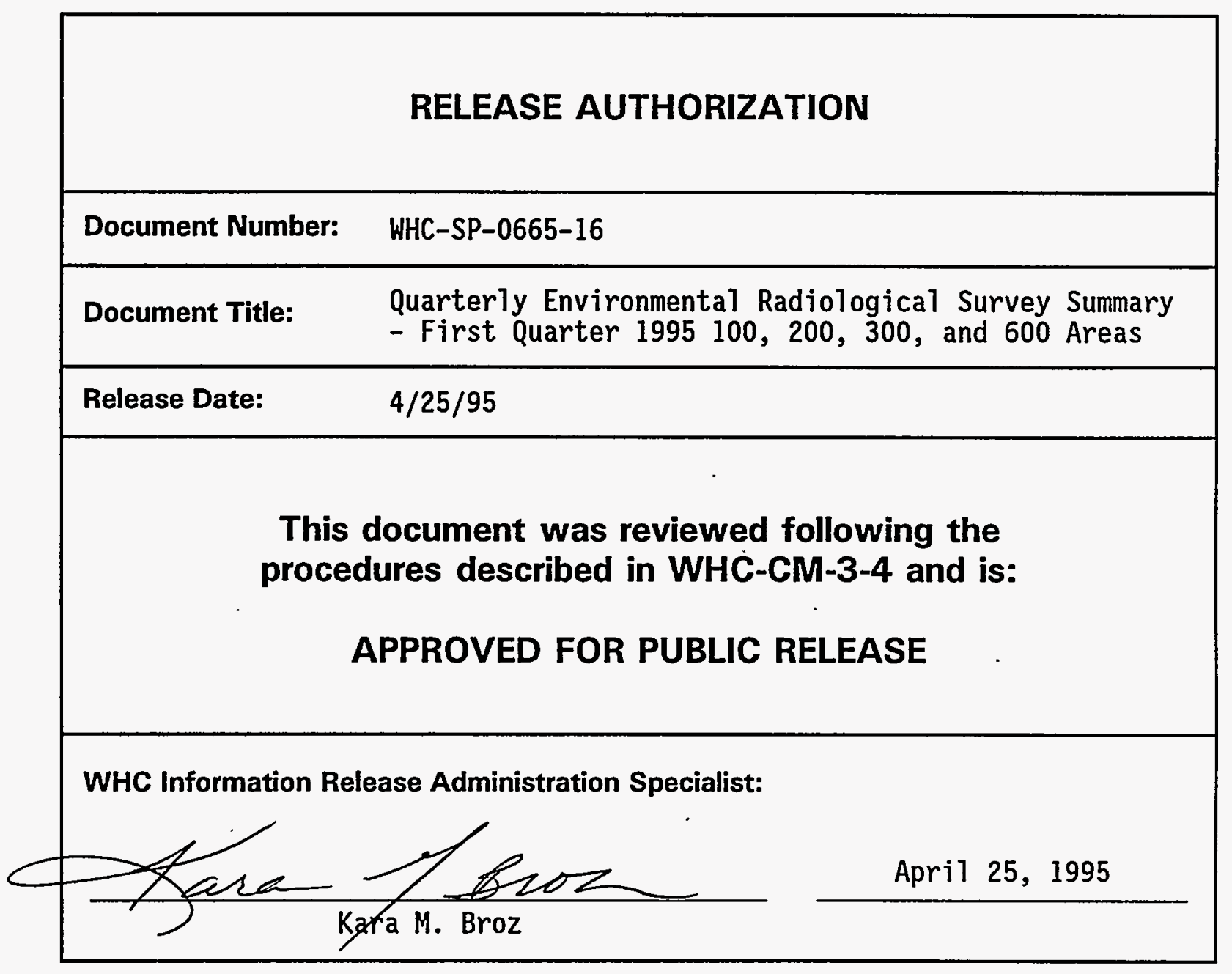


HHC-SP-0665-16

APPROVAL PAGE

PREPARED BY

REVIEWED BY

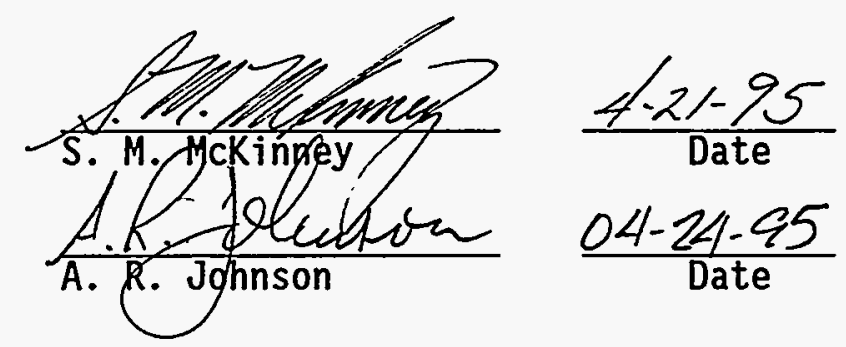

APPROVED BY:

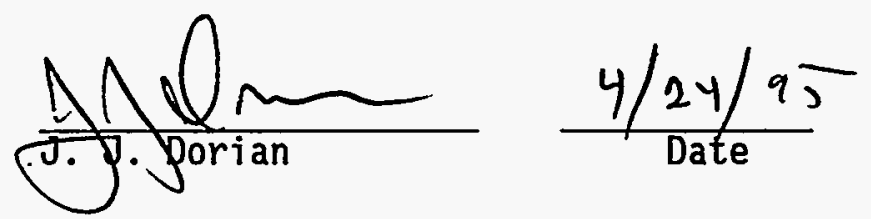


WHC-SP-0665-16

\section{QUARTERLY \\ ENVIRONMENTAL RADIOLOGICAL SURVEY SUMMARY \\ $100,200,300,400$, and 600 Areas \\ lst Quarter 1995}

S. M. McKinney

ENVIRONMENTAL MONITORING AND INVESTIGATIONS NEAR-FIELD MONITORING 


\section{EXECUTIVE SUMMARY}

This report provides a summary of the radiological surveys performed in support of the operational environmental monitoring program at the Hanford Site. The First Quarter 1995 survey results and the status of actions required from current and past reports are summarized below:

- All the routine environmental radiological surveys scheduled during January, February, and March 1995 were completed with the exception of the french drains within the PFP exclusion fence and the 600 area road surveys.

- One hundred twenty six environmental radiological surveys were performed during this period, thirty four at the active waste sites and 92 at the inactive waste sites.

Contamination above background levels was found at eleven of the active waste sites and four of the inactive waste sites. Contamination levels as high as 1,000,000 disintegrations per minute $(\mathrm{dpm})$ were reported. Of these contaminated surveys four were in Surface Contamination (SC) areas and eleven were in Underground Radioactive Materiat (URM) areas or unposted. The contamination found within the URM areas was immediately cleaned up and no further action was required with the exception of a contaminated wooden drain cover at 216-B-51 and a contaminated marker post found at UN-216-E-10 which were marked as surface contamination. Radiation Problem Reports (RPR's) were issued and the sites were turned over to the landiord for further action if required.

- No Compliance Assessment Reports (CARs) were issued for sites found out of compliance with standards identified in WHC-CM-7-5, Environmental Compliance.

- Three Surveillance Compliance/Inspection Reports (SCIRs) were closed during the First Quarter of 1995.

- Eight open SCIRs had not been resolved.

Responsibilities for the unresolved SCIRs are as follows:

LANDLORD

Environmental Restoration

Contractor (ERC)

B Plant

PUREX

Tank Farm Operations (TFO)

\section{OPEN SCIR/CAR}




\section{TOP TEN PRIORITY RANKING}

Below is a listing of the top ten waste sites in order of highest priority ranking for contamination control. The waste site may have an open SCIR of CAR identifying the contamination. An explanation of the prioritization system is on page 12 of this report. Priority rankings of the open SCIRs and CARs are listed in Table 1.

\section{$\underline{\text { SITE }}$}

1. 241-C Tank Farm Perimeters

2. 241-B Tank Farm Perimeters

3. 241-BX-BY Tank Farm Perimeters

4. UN-216-E-36 216-B-64 Basin Area

5. 241-S, SX, SY Tank Farm Perimeters

6. UN-216-E-5 241-B-154

7. UN-216-E-16 TC-4 R.R. Spur

8. 241-U Tank Farm Perimeters

9. UN-216-E-6 241-BX-155 DIVERSION BOX

10. UN-216-W-35 207-U RETENTION BASIN
CUSTODIAN SCIR/CAR

TFO

9008EP200-095

TFO

8909EP200-036

TFO

9007EP200-056

B-Plant 9110ERI-001

TFO

9208ERI-006

TFO

8910EP200-043

PUREX 8901EP200-001

TFO

9203ERI-002

TFO

None

TFO

None 
WHC-SP-0665-16

TABLE OF CONTENTS

EXECUTIVE SUMMARY ................... i

TOP TEN PRIORITY RANKING ............... . .

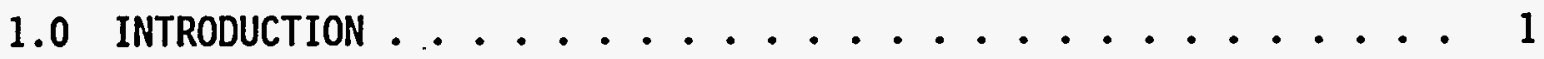

AREA RADIOLOGICAL CONTAMINATION ILLUSTRATIONS ...... 2-11

2.0 PROGRAM DESCRIPTION ...................... 12

2.1 ENVIRONMENTAL RADIOLOGICAL SURVEY PROGRAM OBJECTIVES . . 12

2.2 PRIORITY RANKING SYSTEM . . . . . . . . . 12

2.3 ENVIRONMENTAL STANDARDS .............. 13

2.4 COMPLIANCE ASSESSMENT REPORTS . . . . . . . . 15

2.5 SURVEY METHODS AND PROCEDURES . . . . . . . . . 15

2.5.1 ROAD SURVEYS .

2.5.2 WASTE SITES AND OTHER RADIATION AREA SURVEYS ... 16

3.0 SURVEY RESULTS . . . . . . . 17

3.1 ENVIRONMENTAL RADIOLOGICAL SURVEY SUMMARY $\ldots \ldots \ldots \ldots$

3.2 COMPLIANCE ASSESSMENT REPORTS ISSUED . . . . . . . 18

3.3 COMPLIANCE/SURVEILLANCE REPORTS CLOSED ........ 18

3.4 STATUS OF OPEN SURVEILLANCE AND COMPLIANCE REPORTS $\ldots . .18$

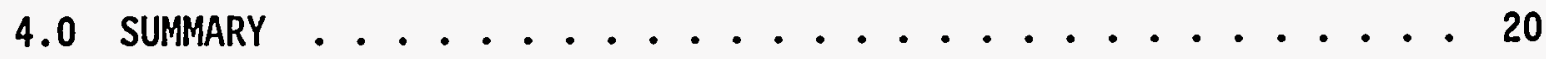


WHC-SP-0665-16

\subsection{INTRODUCTION}

Routine radiological surveys are part of the near-facility environmental monitoring program which monitors and helps direct the reduction of the radiologically controlled areas at the Hanford Site. The routine radiological surveys are performed by the Southern Area Remediation Support Group and the Site Surveillance Radiological Control Group as directed by Near-Field Monitoring. The surveys included in this program consist of inactive waste sites; outdoor radiological control areas; tank farm perimeters and associated diversion boxes, lift stations, and vent stations; perimeters of active or uncovered waste sites such as burial grounds, retention basins, ponds, process trenches, and ditches; and road and rail surfaces (Figures 1 through 10). This report provides a summary of the radiological surveys performed during the First Quarter of 1995. The status of corrective actions required from current and past reports are also discussed.

A waste site survey schedule, WHC-SP-0098-6, is developed by Near-Field Monitoring and approved by the Southern Area Remediation Support Group and the Site Surveillance Radiological Control Group. Near-Field Monitoring reviews the radiological survey reports and files a copy for historical purposes and reference. Radiological conditions are tracked and trends noted. All sites are surveyed at least once each year. The survey frequencies for particular sites are based on site history, radiological conditions, and general maintenance. Special surveys may be conducted at irregular frequencies if conditions warrant (e.g., growth of deep-rooted vegetation is noted at a waste site). Radiological surveys are conducted to detect surface contamination and document changes in vegetation growth, biological intrusion, erosion, and general site maintenance conditions. Survey data are compared with standards identified in WHC-CM-7-5, Environmental Compliance, as well as previous surveys to recognize possible trends, assess environmental impacts, and help determine where corrective actions are needed.

Landlords of the sites found out of compliance may be issued a Radiological Problem Report (RPR) from the Environmental Restoration Site Investigative Survey and Site Surveillance Radiological Control Groups. Should the landiord fail to respond to the identified problem in a timely manner, or if the corrective action will require a long-term commitment, Near-Field Monitoring will issue a Compliance Assessment Report (CAR). The Compliance Assessment Report, formerly called Surveiliance Compliance Inspection Report (SCIR), is tracked to completion by Near-Field Monitoring. Open SCIRs and CARs are listed in Table 1 of this report.

The surveys scheduled for this program consist of inactive waste sites; outdoor radiological control areas; tank farm perimeters and associated diversion boxes, lift stations, and vent stations; perimeters of active or uncovered waste sites such as burial grounds, retention basins, ponds, process trenches, and ditches; and road and rail surfaces. Surveillance of the active nuclear facilities and inside the tank farms is the responsibility of the facility. These radiological surveys are to determine surface radiological conditions and do not constitute a release survey. Therefore, surveys that detect no contamination in radiologically controlled areas do not release the site from control but may result in a posting status change. 


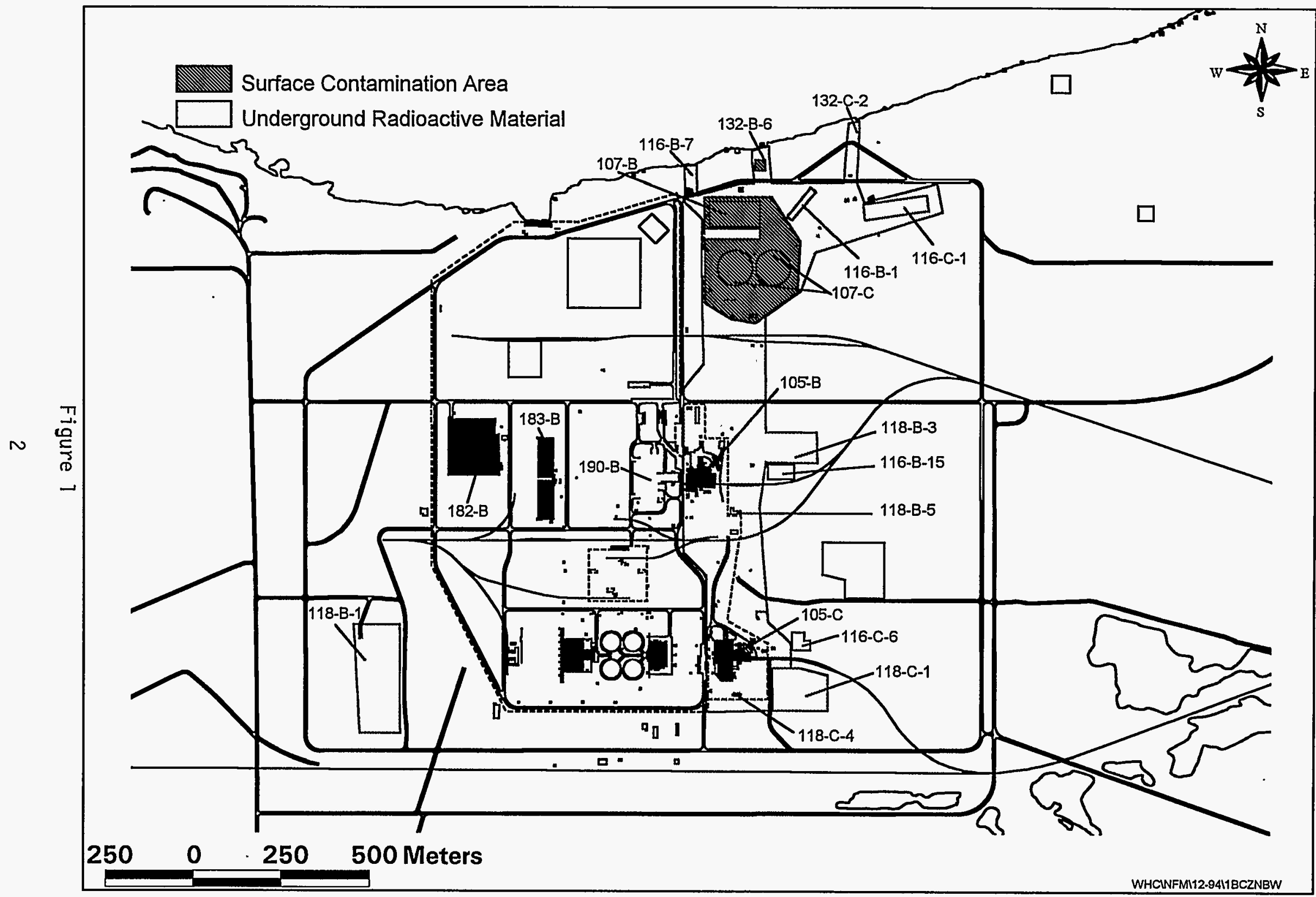

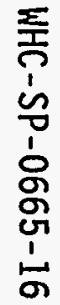




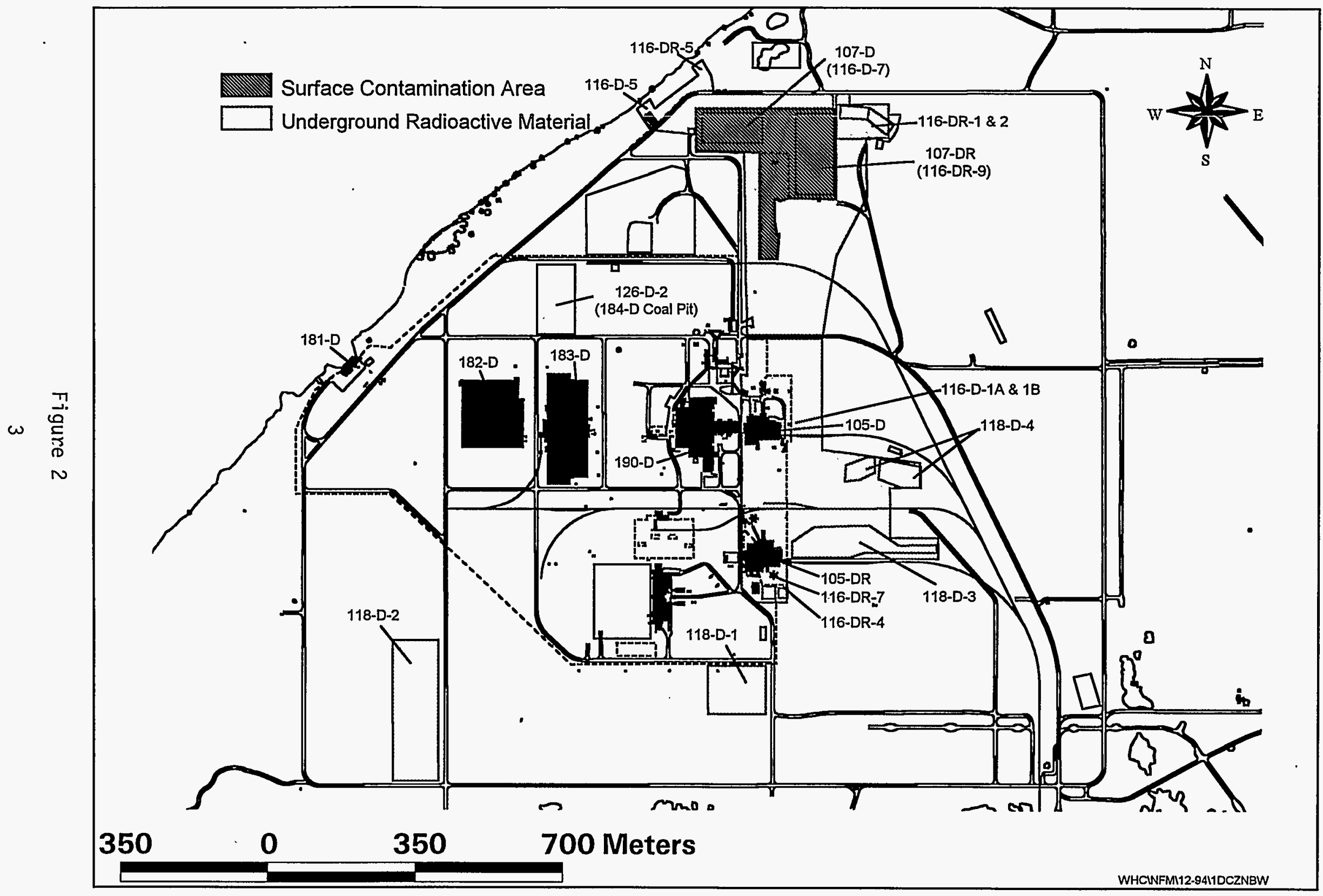

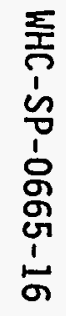


WHC-SP-0665-16

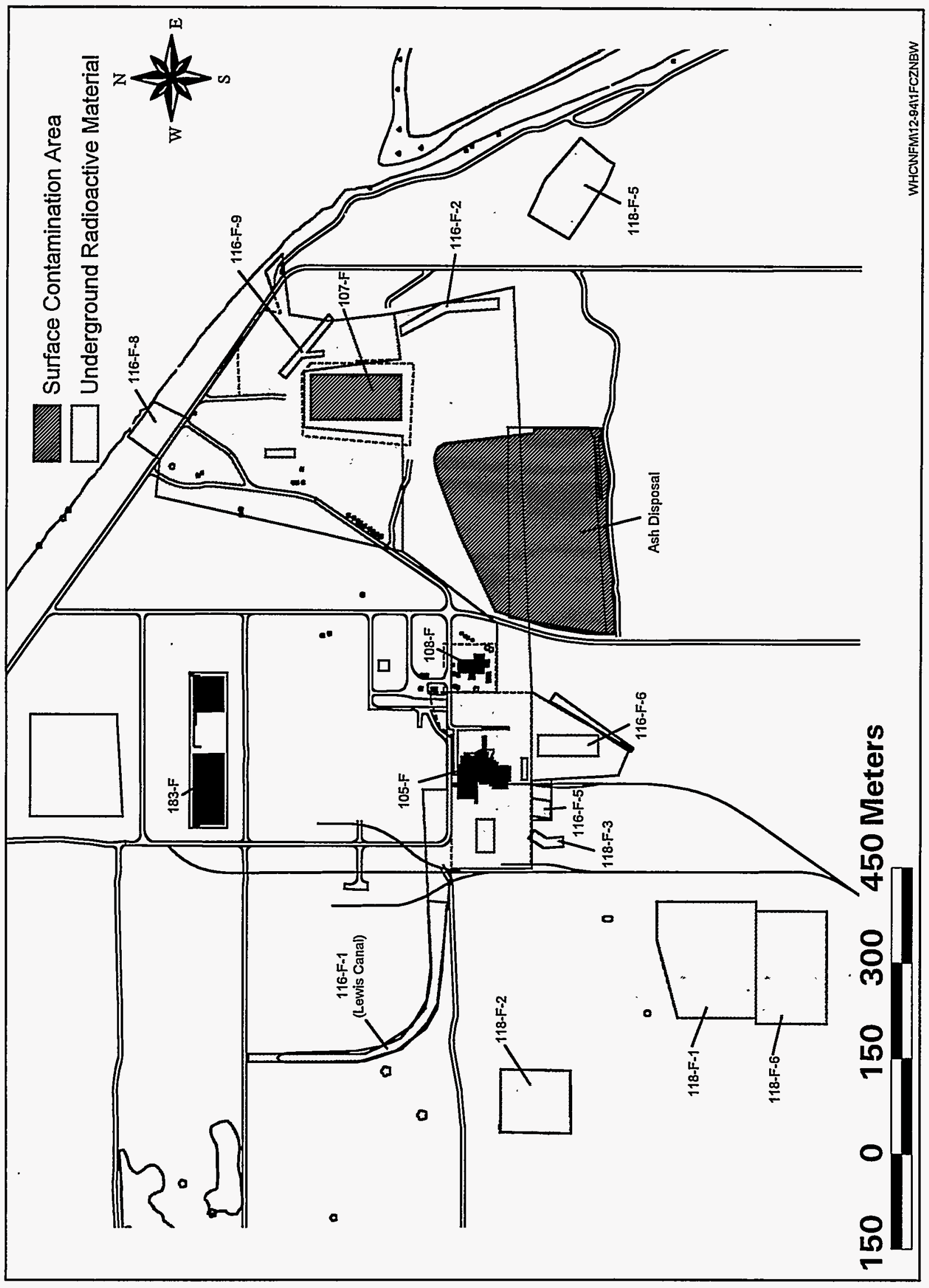

Figure 3 
WHC-SP-0665-16

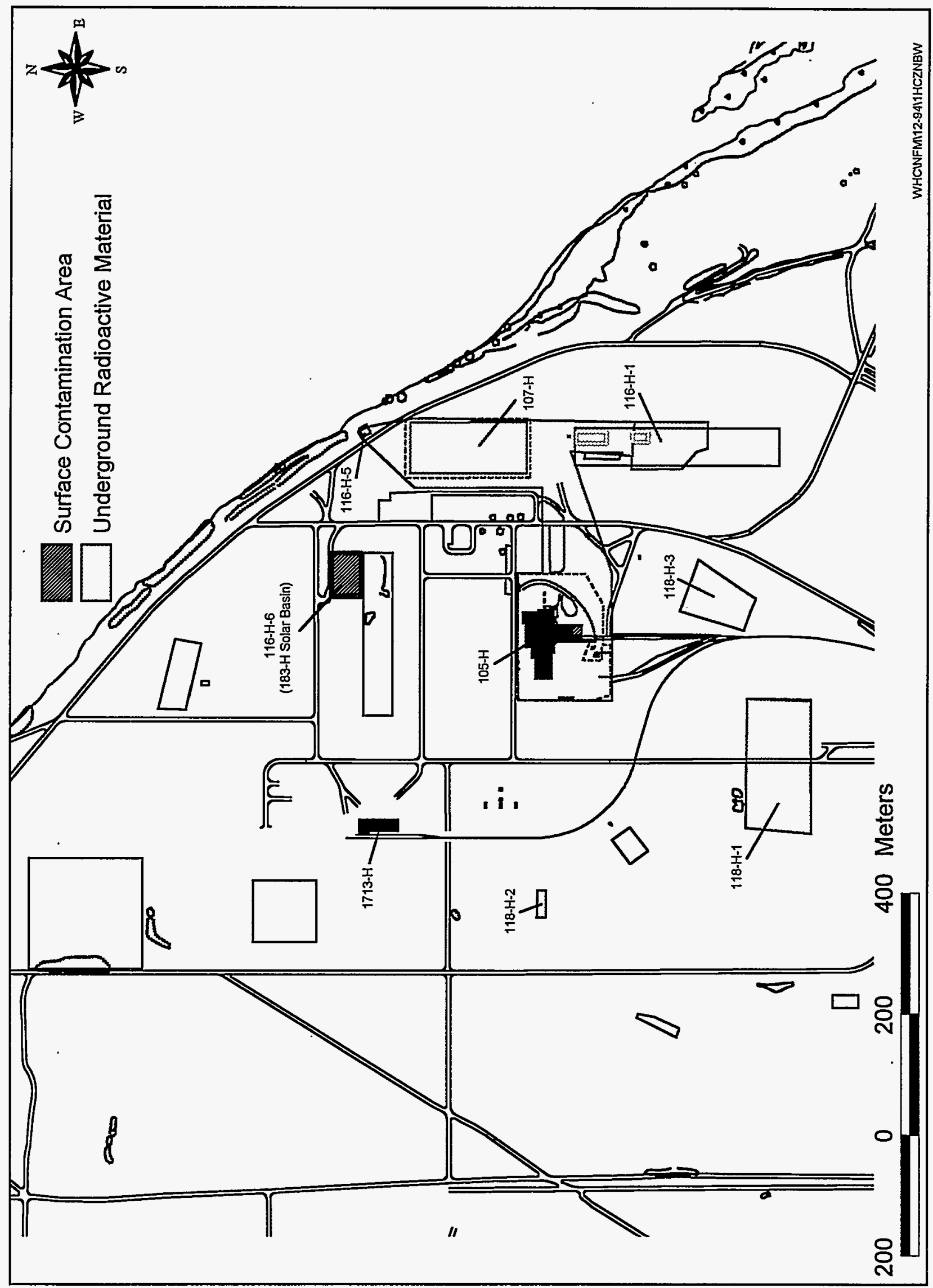

Figure 4 
WHC-SP-0665-16

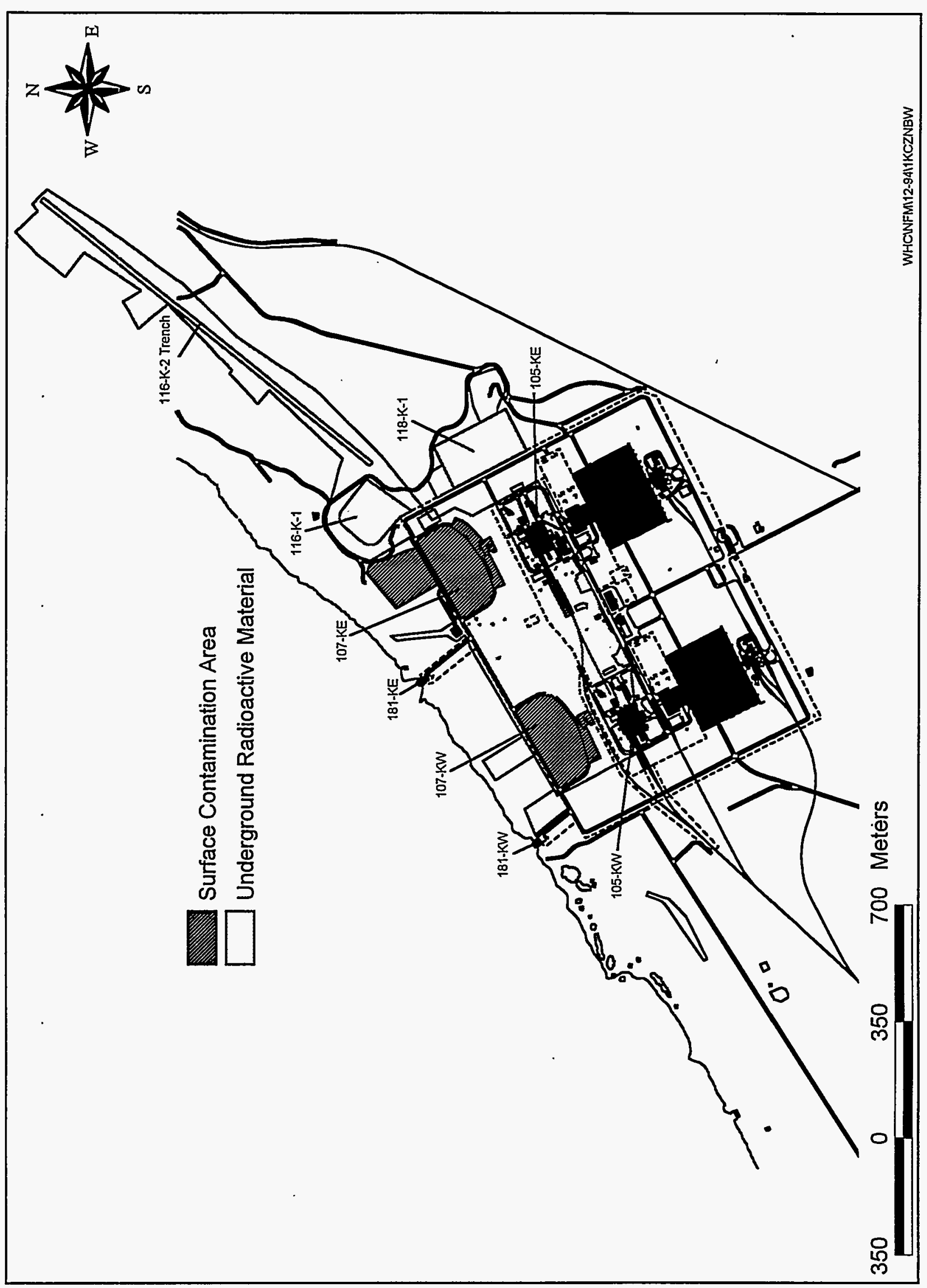

Figure 5 


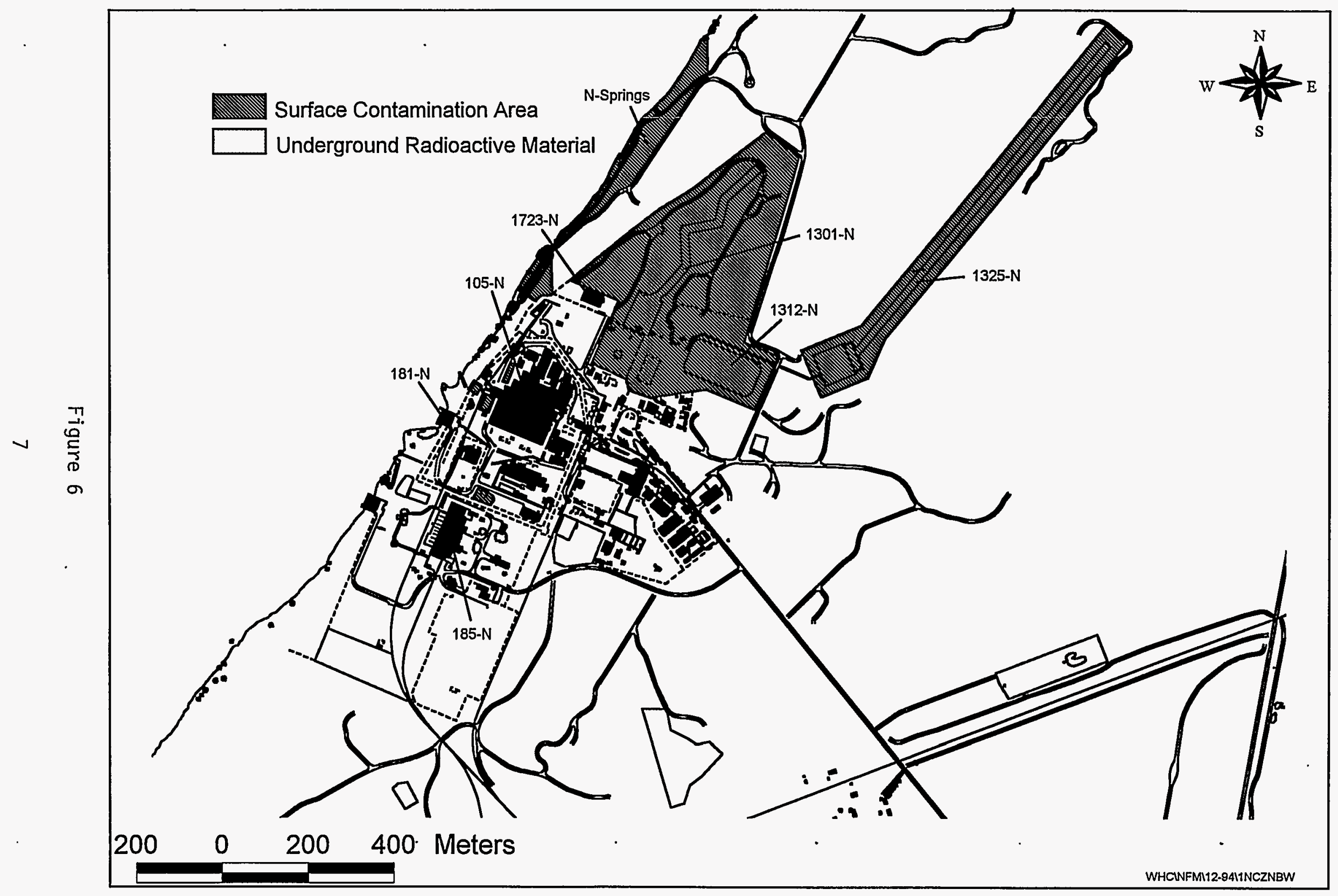

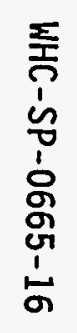




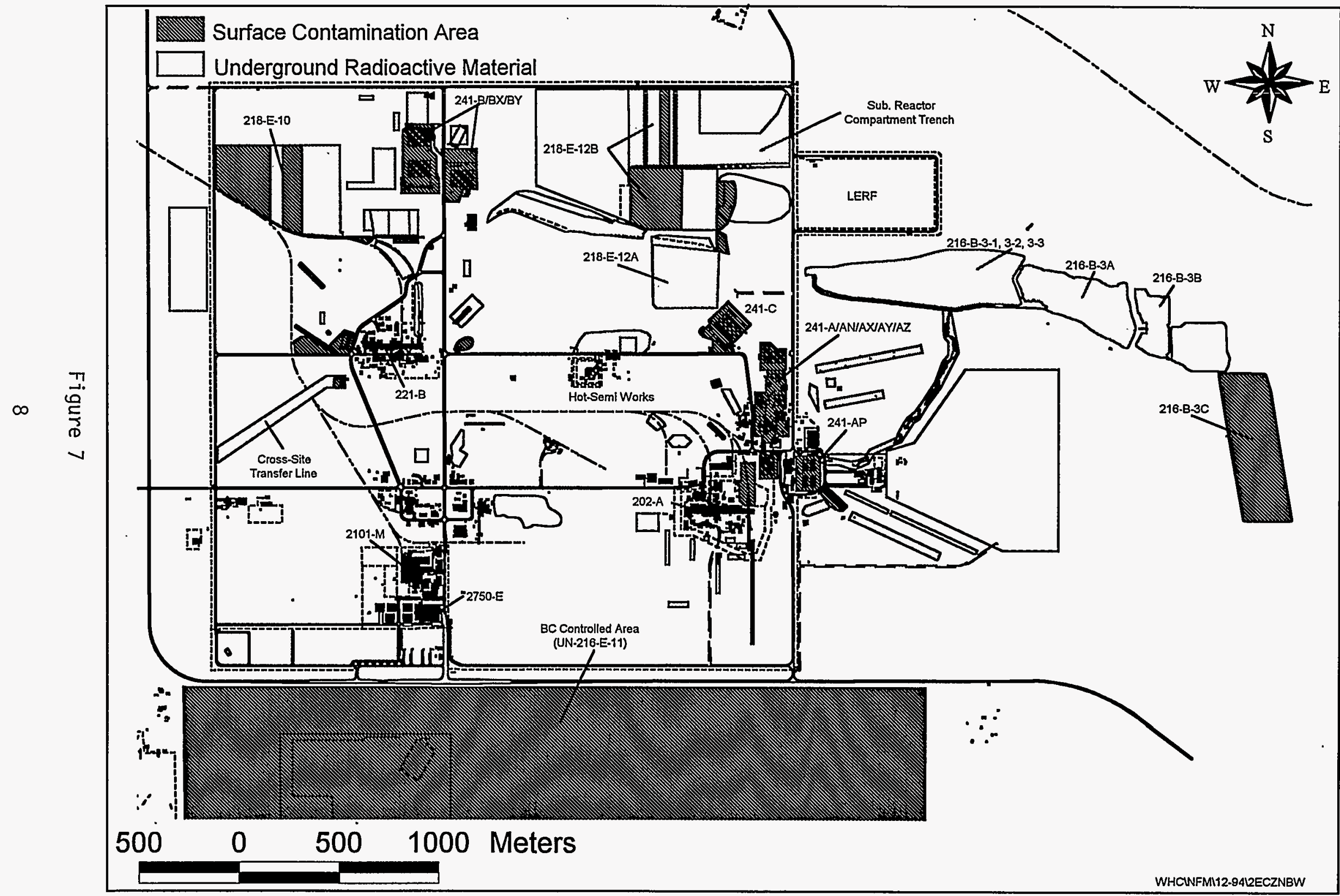


WHC-SP-0665-16

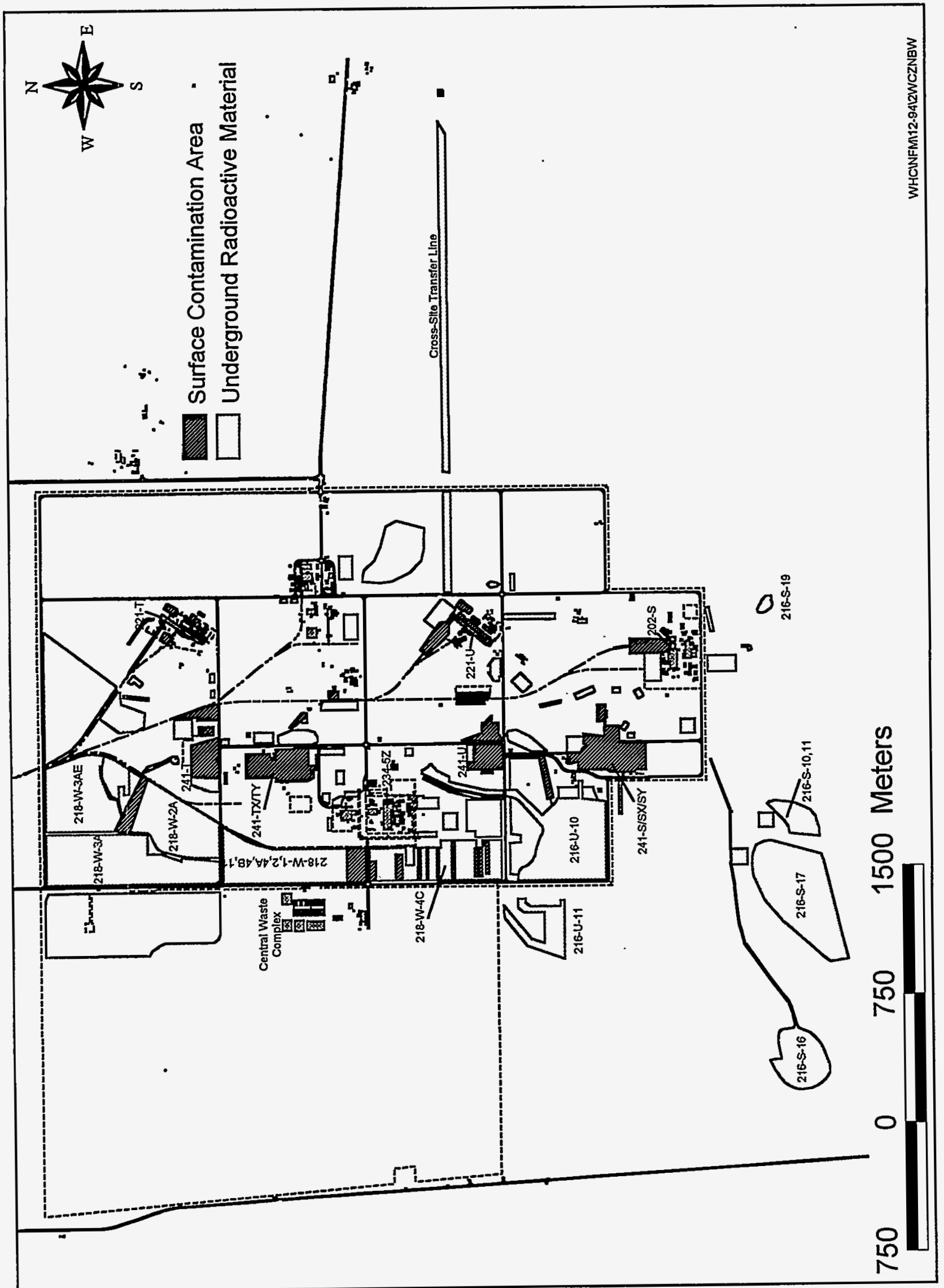

Figure 8 
WHC-SP-0665-16

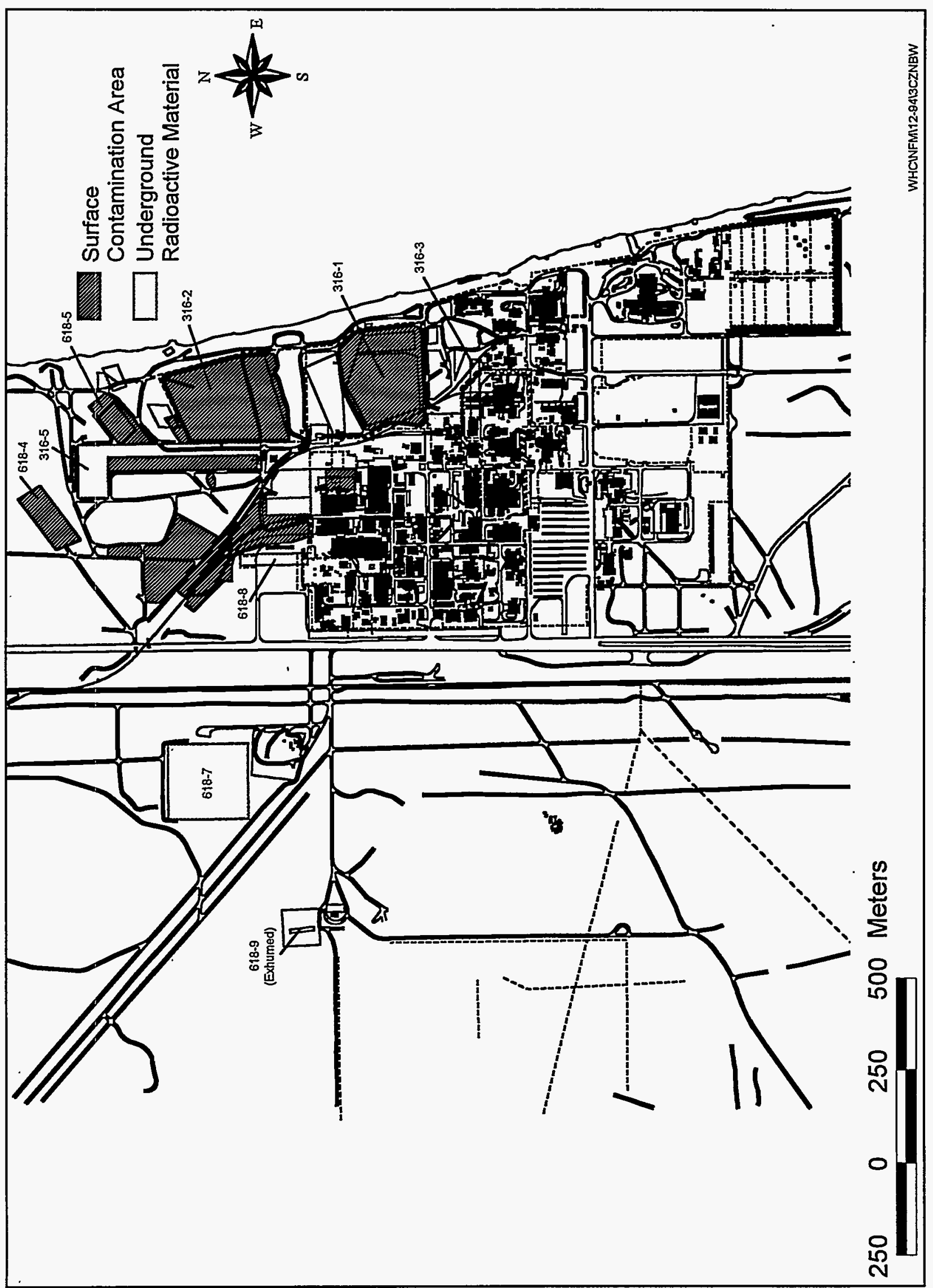

Figure 9 


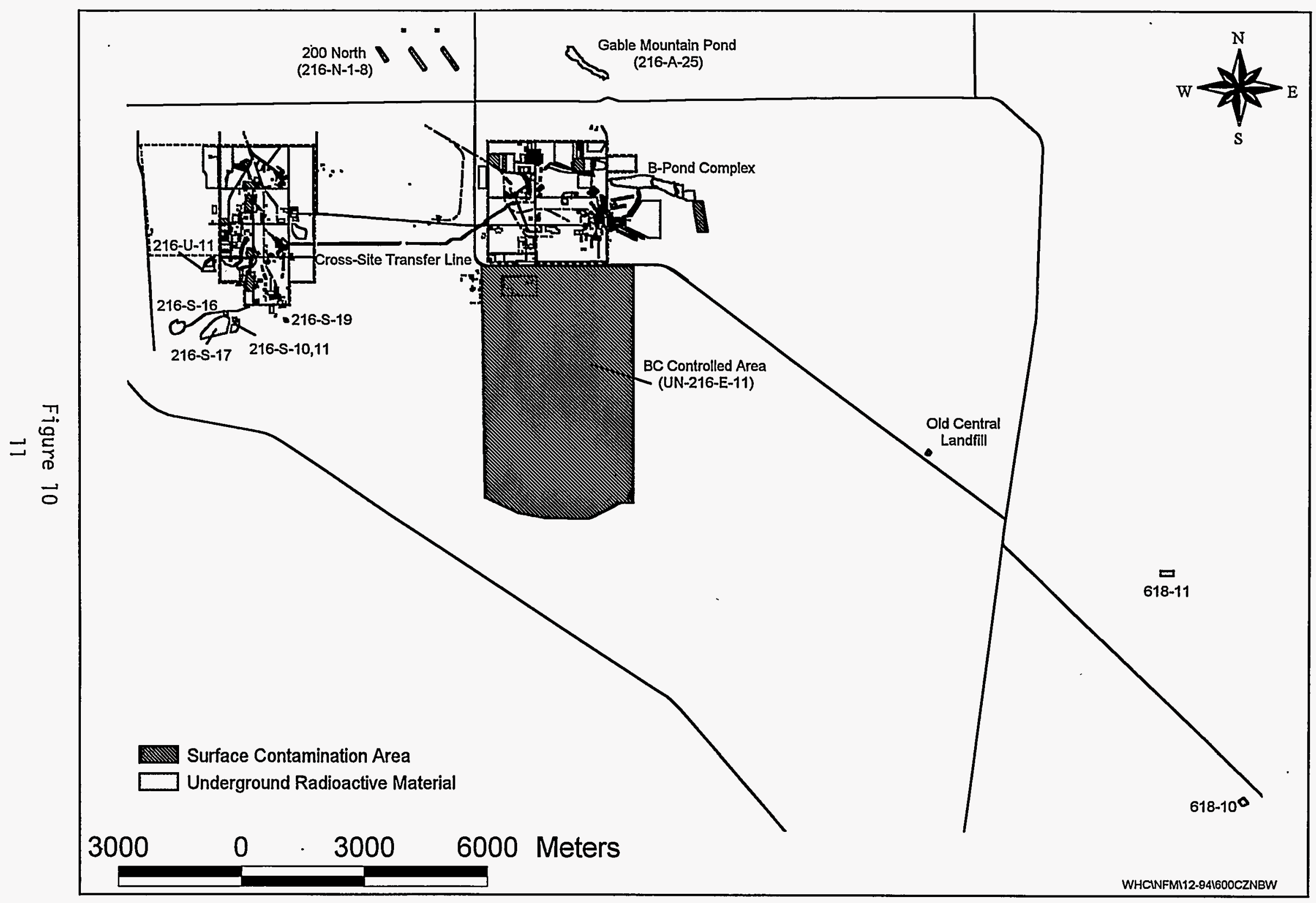

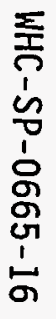




\subsection{PROGRAM DESCRIPTION}

\subsection{ENVIRONMENTAL RADIOLOGICAL SURVEY PROGRAM OBJECTIVES}

Environmental radiological surveys are performed to:

- Identify priorities for environmental cleanup or stabilization of surface contamination.

- Determine compliance with Department of Energy requirements and applicable policies and standards regarding operational control and environmental and radiological protection.

- Identify trends in radioactive contamination levels and radioactive migration at waste sites and other radiation areas.

- Assess the surface integrity of solid and liquid waste disposal sites.

- Monitor for unplanned releases of radioactivity to the operations area environment.

\subsection{PRIORITY RANKING SYSTEM}

A numerical ranking system is used for sorting open SCIRs and CARs relative to environmental radiological concerns. This system. provides a priority guideline to responsible landlords for clean-up or stabilization of surface-contaminated areas.

A numerical value is assigned based on the level of contamination, site accessibility, and contamination mobility. Site histories are examined by reviewing past and present radiological surveys. Contamination levels from 1,000 counts per minute (cpm) to greater than $10 \mathrm{mrad} / \mathrm{hr}$ (as measured on Radiological Control's field survey instruments) are considered and assigned a numerical value of 1 (7owest value) to 5 (greatest value). Any removable alpha contamination will be considered a high priority and will receive a contamination value of 5 . Location is evaluated for accessibility. A restricted area would receive the lowest point value of 1 progressing up to a value of 5 where the public could have access. Mobility refers to contamination that can be or has a history of being transported from where it was originally identified to places outside of the radiologically posted area. Fixed contamination would receive a value of 1 progressing to contamination that is blown by the wind or the result of biological uptake receiving a value of 5 . The rankings (a maximum of 15 points is possible) are noted on Table 1.

It should be noted that this system is not intended to be a total risk assessment, but rather a way of communicating environmental significance to the landlords and their program offices. Other elements of the site clean-up process are considered such as costs, location, political emphasis and engineering strategies before a site is actualiy remediated. 


\subsection{ENVIRONMENTAL STANDARDS}

Radiation survey data are used to determine compliance of Radioactive Waste Sites with WHC-CM-7-5, Environmental Compliance, Section 6.0 (Rev. 1) and BHI-EE-02, Environmental Requirements, Section 7.0 (Rev. 0), requirements.

Applicable requirements include the following:

1. Engineered barriers shall be provided, where applicable, over the disposal site to inhibit radionuclide transport to the surface.

2. Inactive waste site boundaries shall be accurately and permanently marked with Hanford plant standard (AC-5-40) approved concrete marker posts. Sites never used and those that are no longer contaminated do not require marker posts.

3. Facility effluent lines which are potential discharge points shall be isolated, capped, or sealed off to prevent accidental releases to inactive sites. This shall be verified and documented.

4. Active and inactive waste sites shall be inspected and surveyed at least annually.

5. One or more of the following actions shall be taken when contamination of any type is detected (either new or in excess of action limits) to prevent the migration or mobilization of the contamination:

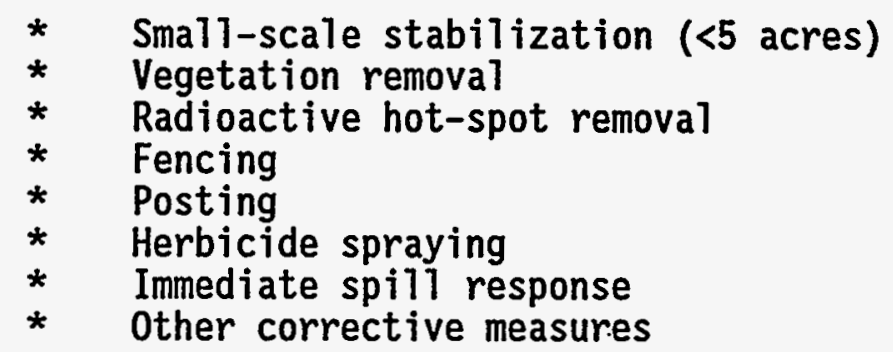

6. Information regarding all suspect waste sites or newly identified waste sites shall be provided for documentation into the Waste Identification Data System (WIDS) database.

7. Inactive waste sites shal1 be maintained to control deeprooted vegetation that could provide transport of contamination to the surface through plant uptake. The application of herbicides or pesticides may be required. 
Near-Field Monitoring is responsible for:

1. Establishing radiological survey schedules of active and inactive radiological waste sites.

2. Conducting compliance assessments of active and inactive waste sites to determine compliance with the physical and radiological requirements.

3. Compiling and maintaining copies of historical records, including radiological survey reports, compliance assessment reports (CARs), surveillance/compliance inspection reports (SCIRs), and other information for each active and inactive radioactive waste site.

4. Trending radiological data, and issuing reports on the status of radiological surveys and compliance assessments for active and inactive radioactive waste sites.

5. Reviewing any proposed activity, other than routine inspections, that may impact or may be impacted by any active and inactive waste site.

6. Issuing a compliance assessment report or notifying the facility manager or area landlord, as appropriate, when violations of the requirements occur.

The above mentioned requirements apply to all active and inactive radioactive waste sites which include cribs, trenches, ditches, ponds, French drains, burial grounds and other areas of concern such as tank farm perimeters and radioactive contamination due to spills or releases. Interiors of tank farms and radiation areas where operations are ongoing are not included, because monitoring and tracking is done by Tank Waste Remediation System and other requirements are applicable to these areas.

In order to compare standards [as established in WHC-CM-7-5, Section $6.0]$ and field instrument values, a conversion factor is necessary. This conversion factor has been established where 20,000 disintegrations per minute $(\mathrm{dpm})(2,000 \mathrm{cpm})$ are approximately equivalent to one millirem per hour for beta-emitting radionuclides. It must be understood that converting field instrument values, which include both beta and gamma energies, is approximate and does not allow for absolute precision. 


\subsection{COMPLIANCE ASSESSMENT REPORTS}

When it is determined that conditions at a site are not in compliance with the standards established in $\mathrm{HHC}-\mathrm{CM}-7-5$, the appropriate area landlord is notified. If the noncompliance is not corrected as a resuit of Radiological Control's Radiation Problem Report (RPR) Near-Field Monitoring may issue a Compliance Assessment Report. Resolution of a CAR is considered initiated when a formal corrective action plan is provided to and accepted by Near-Field Monitoring. However, for tracking purposes it will remain on file and appear in subsequent Environmental Radiological Survey Reports until satisfactory completion of the plan is demonstrated. A visual inspection by Near-Field Monitoring and/or a post-corrective action radiation survey by Radiological Control is required before closing a CAR. If a compliance plan is not provided to Near-Field Monitoring within one month, a second notice is issued.

A CAR may be issued for conditions which pose a probable threat of radiological contamination to uncontrolled areas. These conditions include the presence of deep-rooted vegetation, animal intrusion, or obvious migrating contamination. Once the contamination is contained on or removed from a site for which a CAR has been issued, the report will be closed after a follow-up radiation survey has indicated that no further adverse environmental impact is evident.

\subsection{SURVEY METHODS AND PROCEDURES}

Surveys documented by this report include road/railroad surfaces, cribs, stabilized burial grounds, covered ponds and ditches, tank farm perimeters, active burial ground perimeters, unplanned release sites and other radiation areas. Methods and procedures for these surveys can be found in WHC-CM-7-4, Operational Environmental Monitoring; WHC-CM-1-6, WHC Radiation Control Manual; HSRCM-1, Hanford Site Radiological Control Manual; and WHC-IP-0718, Health Physics Procedures.

\subsubsection{ROAD/RAILROAD SURVEYS}

Road Surveys are performed with a Mobile Surface Contamination Monitor (MSCM) vehicle equipped with sodium iodide detectors or plastic scintillators. Railroad Surveys are conducted with a vehicle equipped with "high railers", which allows the vehicle to travel both on the roads or railroads, and sodium iodide detectors. The detector height is adjustable in all cases and the average survey height is one foot.

The vehicles are driven at less than five miles per hour. If activity above background is detected, the vehicle is stopped and a thorough survey is made with an Eberline Model BNH-1 portable survey instrument equipped with a pancake type probe to identify the extent of the contamination. Appropriate management is notified if road/railroad contamination is identified, and corrective actions are initiated. 


\subsubsection{WASTE SITES AND OTHER RADIATION AREA SURVEYS}

Surveys at waste sites and other radiation areas may be conducted with vehicles equipped with radiation detection instruments or with hand-held field instruments. Field instrument survey results are reported in disintegrations per minute (using a conversion factor of $10 \mathrm{dpm} / \mathrm{cpm}$ ) as detected by using a Geiger-Mueller detector for beta/gamma radiation equipped with a pancake type probe. Alpha survey results are reported in disintegrations per minute as measured with a portable alpha meter (PAM) or a portable alpha counter (PAC-6). Surveys include the perimeter and portions of the ground surface of radiation areas. Wherever possible, smear surveys are made on the surface of exposed equipment and other hard surfaces within a radiation area. Vegetation, animal burrows, and animal feces are also monitored to detect biological transport. Detailed survey practices and procedures are described in WHC-CM-7-4, Operational Environmental Monitoring; WHC-CM-1-6, HHC Radiation Control Manual; HSRCM-1, Hanford Site Radiological Control Manual; and WHC-IP-0718, Health Physics Procedures. 


\subsection{SURVEY RESULTS}

A11 the routine environmental radiological surveys were completed during January, February, and March 1995, with the exception of the french drains within the Plutonium Finishing Plant (PFP) exclusion fence and the 600 area road surveys. The surveys of the french drains within the PFP exclusion will be performed during the second quarter by the PFP radiological control group and the 600 area road surveys will be completed once the survey equipment is repaired. Surveys of inactive waste disposal sites included cribs, trenches, burial grounds, covered ponds and covered ditches. The survey schedule for environmental sites is outlined in WHC-CM-7-4, Section 12 , and in WHC-SP-0098-5, Rev. 0.

One Hundred and twenty six environmental radiological surveys were performed during the first quarter of 1995. Contamination above background levels was found at eleven of the surveyed active waste site areas and four of the inactive waste site areas. Contamination levels ranging from a low of 2,000 dpm to a high of $1,000,000 \mathrm{dpm}$ were reported. Four of the contaminated surveys were found in SC areas and eleven were found in URM or unposted areas.

Nine of the eleven contaminated sites found in URM areas and two of the contaminated sites found in SC areas were immediately cleaned up and no further action was required. Radiation Problem Reports (RPR's) were issued and the remaining sites were turned over to the landlord for further action.

\subsection{RADIOLOGICAL SURVEY SUMMARY}

This report provides a synopsis of the radiological survey results conducted in January, February and March of 1995. The stabilization efforts for the 116-H-2 Crib, 216-S-9 Crib, 216-T-4 Pond, 216-T-4-1 Ditch, 216-U-14 Ditch between Cooper Ave and 16th Street, the cross-site corridor and vent station 241-EH-151 (UN-216-E-41), and the UN-216-W-24 and 30 sites were completed during this period. The recontaminated portions of the 216$\mathrm{U}-1$ and 216-U-2 Cribs and the 216-U-10 and 216-U-11 ponds were corrective action backfilled and down posted to URM.

The placement of sealant in the tank farms is on going.

The stabilization of the cross site corridor and the vent station, a major effort, was completed during this period. It has been one of the high priority contaminated sites since it was discovered in 1988. The large surface area and the amount of funding required for stabilization of the site has prevented earlier efforts. Revegetation is scheduled to begin in the fall of 1995. 
TABLE 1

OPEN SCIRS AND CARS

(maximum 15 points)

\begin{tabular}{|c|c|c|c|c|c|c|}
\hline SCIR/CAR & SITE & $\begin{array}{c}\text { DATE } \\
\text { INITIATED }\end{array}$ & $\begin{array}{c}\text { MONTHS } \\
\text { OPEN } \\
\end{array}$ & ECD & $\begin{array}{c}\text { SITE } \\
\text { RANKING } \\
\end{array}$ & CUSTODIAN \\
\hline ESC-85-019 & UN-216-E-23, RR Spur No. of B-Plant & $11 / 01 / 85$ & & CLOSED & & B-PLANT \\
\hline ECU-86-048 & UN-216-W-30 NE OF 241-S,SX,SY & $10 / 01 / 86$ & & CLOSED & & ERC \\
\hline 8901EP200-001 & UN-216-E-16 TC-4 RR SPUR & $01 / 01 / 89$ & 71 & $04 / 26 / 93 *$ & 8 & PUREX \\
\hline 8909EP200-036 & 241-B FARM PERIMETERS & $09 / 01 / 89$ & 63 & $09 / 30 / 95$ & 13 & TF0 \\
\hline 8910EP200-043 & $U N-216-E-5 \quad 241-B-154$ & $10 / 01 / 89$ & 62 & $09 / 30 / 95$ & 10 & TFO \\
\hline 9007EP200-056 & BX-BY TANK FARM PERIMETERS & $07 / 20 / 90$ & 51 & $12 / 30 / 95$ & 13 & TFO \\
\hline 9008EP200-068 & C-TANK FARM PERIMETERS & $08 / 13 / 90$ & 50 & $12 / 30 / 95$ & 13 & TFO \\
\hline 9012EP200-095 & UN-216-E-41 X-SITE TRANSFER LINE & $12 / 05 / 90$ & & CLOSED & & TF0 \\
\hline 9110ERI-001 & UN-216-E-36 216-B-64 BASIN & $12 / 25 / 91$ & 32 & $\mathrm{TBD} *$ & 12 & B-PLANT \\
\hline 9203ERI-002 & 241-U TANK FARM PERIMETERS & $03 / 17 / 92$ & 29 & $09 / 30 / 95$ & 8 & TFO \\
\hline 9208ERI-006 & 241-S, SX, SY TANK FARM PERIMETERS & $08 / 14 / 92$ & 25 & $09 / 30 / 95$ & 12 & TFO \\
\hline & & & & & & \\
\hline & & & & & & \\
\hline & & & & & & \\
\hline & & & & & & \\
\hline & & & & & & \\
\hline
\end{tabular}




\subsection{SUMHARY}

A11 the routine outdoor radioactive surveys were completed during the first quarter of 1995 in the 100, 200-East/West, 300 and 600 areas with the exception of the french drains within the PFP exclusion fence and the 600 area road surveys.

No unsatisfactory CARs were issued (Section 3.2)

Three SCIRs were closed (Section 3.3)

Eight SCIRs remained open (Table 1). Open reports have been addressed and clean-up plans with completion dates are being developed or to be provided to Near-Field Monitoring. However, the corrective actions on two of the eight SCIRs that remain open are currently delinquent.

\section{RADIOLOGICAL POSTING CHANGES}

During the first quarter of 1995, 25.6 hectares (63.3 acres) were radiologically down posted from SC to URM or released from posting.

Radiological posting changes, by waste site, noted during the first quarter of 1995 are as follows:

The 116-H-2 Crib was stabilized and down posted from SC to URM, 0.04 hectares ( 0.1 acres).

The 216-S-9 Crib was stabilized and down posted from SC to URM, 0.28 hectares (0.7. acres).

The 216-T-4 Pond was stabilized and down posted from SC to URM, 6.5 hectares ( 16.0 acres).

The 216-T-4-1 Ditch was stabilized and down posted from SC to URM, 0.065 hectares ( 0.16 acres).

The recontaminated portions of the 216-U-1 and 2 Cribs, 216-U-10 and 11 ponds were corrective action backfilied and down posted from SC to URM.

The 216-U-14 Ditch between Cooper Ave and 16th Street was backfilled and stabilized and down posted from SC to URM, 1.13 hectares (2.8 acres).

The cross-site corridor and vent station 241-EH-151 (UN-216-E-41) were stabilized and down posted from SC to URM 11.83 hectares (29.24 acres).

The UN-216-W-24 and 30 sites were stabilized and down posted from SC to URM or released, 2.6 hectares (6.5 acres) and 4.1 hectares ( 7.75 acres) respectively.

(SC = Surface Contamination $\quad$ URM $=$ Underground Radioactive Material) 


\section{DISTRIBUTION}

Number of Copies

ONSITE

44

WESTINGHOUSE HANFORD COMPANY

I. J. Aust in

H. A. Bese 1

T4-01

D. M. Bogen

T1-27

D. E. Buillock

R3-50

D. L. Chase

T4-09

L. P. Diediker

B4-49

J. J. Dorian

T1-30

R. E. Elder

H6-20

R. F. Giddings

T7-37

R. D. Gustayson

N3-06

G. S. Hauger

R1-51

R. E. Heineman

S4-39

A. R. Johnson

S6-65

S. R. Johnson

H6-30

M. E. Juguilon

T7-37

J. L. Lee

B. H. Lueck Jr.

C. L. Looney

B. M. Markes

A. K. McDowe 11

S. M. Mckinney

(6)

L4-94

R2-50

R3-12

H6-06

H6-20

R1-51

D. L. Mitche11

T1-30

H6-32

D. J. Newl and

T7-37

J. L. Parson

S5-66

B. L. Poorman

S5-10

0. L. Rasmussen

R1-51

M. D. Rowe

T1-25

M. P. Rung

G6-06

J. W. Schmidt

H6-20

J. L. Shelor

R2-36

J. E. Thrasher

S6-65

P. L. Treadway

S5-03

R. J. Thomas

R2-82

R. R. Thompson

H6-32

D. J. Watson

X3-79

R. L. Watts

L6-52

O.S.T.I. (2)

L8-07

Central Files

L8-04 
Number of Copies

\section{DISTRIBUTION (continued)}

5

\section{U.S. DEPARTMENT OF ENERGY - Rich 7 and}
G. M. Bell
M. J. Furman
J. B. Hall
P. M. Pak
D. C. Hard

A5-52

S7 -55

A5-55

H4-83

A5-55

PACIFIC NORTHWEST LABORATORY

2
R. L. Dirkes (2)

K6-75

KAISER ENGINEERS

P. I. Thakkar

G3-06

BECHTEL HANFORD, INC.

20

L. K. Ahrens

H6-04

A. I. Davis

$\mathrm{X} 0-21$

L. A. Dietz

$\mathrm{H} 6-07$

D. B. Erb

J. R. Freeman-Pol1 ard (2)

H6-01

K. A. Gano

J. T. Hadley

H. M. Hayward

H6-04

H6-02

H6-03

T7-05

J. E. Hodgson

T7-05

R. A. Hughes

H4-87

W. L. Osborne

R. A. Lewis

T7-05

H4-79

L. A. Mihalik

H4-79

J. E. Parsons

T7-06

H. H. Price

K. A. Smith

C. D. Wade

S. R. Wei 1

D. C. Weekes

H6-04

H4-88

T7-05

H4-79

H4-82 